

P-ISSN: 2349-8528

E-ISSN: 2321-4902

www.chemijournal.com

IJCS 2020; 8(3): 668-673

(C) 2020 IJCS

Received: 22-03-2020

Accepted: 23-04-2020

U Nagabhushanam

Senior Scientist (Agronomy)

Regional Agricultural Research

Station, Warangal, Telangana,

India

P Spandana Bhatt

Scientist (Agronomy),

Rice Research Centre,

Rajendranagar, Hyderabad,

Telangana, India
Corresponding Author: U Nagabhushanam

Senior Scientist (Agronomy), Regional Agricultural Research Station, Warangal, Telangana, India

\section{Effect of sowing dates and nutrient management practices on yield attributes, yield and economics of rice (Oryza sativa $\mathbf{L}$.)}

\section{U Nagabhushanam and P Spandana Bhatt}

DOI: https://doi.org/10.22271/chemi.2020.v8.i3h.9284

\begin{abstract}
A field experiment was conducted to study the "Effect of sowing dates and nutrient management practices on yield attributes, yield and economics of rice (Oryza sativa L.) during Kharif, 2017 at Rice Research Centre, Agricultural Research Institute, Rajendranagar, Hyderabad (TS), India. The experiment was laid out in split plot design with four replications, comprises three main plot treatments i.e., sowing dates $\mathrm{M}_{1}$ - Normal sowing- first fortnight of July, $\mathrm{M}_{2}$ - 15 days after normal sowing (Late sowing) second fortnight of July, $\mathrm{M}_{3}-30$ days after normal sowing (Very late sowing) second fort night of August, six sub plot treatments i.e., $\mathrm{S}_{1}-100 \% \mathrm{RDF}(\mathrm{RDF}+\mathrm{Zn})\left(\mathrm{N}-3\right.$ splits @ 1/3+1/3+1/3), $\mathrm{S}_{2}-100 \% \mathrm{RDF}(\mathrm{RDF}+\mathrm{Zn})$ (N-3 splits@1/2+1/4+1/4), S3- 150\% RDF (RDF+Zn) (N-3 splits@1/3+1/3+1/3), S4- 150\% RDF (RDF+Zn) (N-3 splits@ 1/2+1/4+1/4), S5- 100\% NKZn+150\% P (N-3 splits@ 1/3+1/3+1/3), S 6 - Absolute control (no fertilizers). The results revealed that normal, late sowings were found to be optimum with $100 \%$ RDF $(\mathrm{RDF}+\mathrm{Zn})(\mathrm{N}-3$ splits @ 1/2+1/4+1/4), proved to be better for obtaining maximum grain yield and net returns.
\end{abstract}

Keywords: Rice, sowing dates, nutrient management practices, yield

\section{Introduction}

Rice (Oryza sativa L.) is one of the words most important staple food crops. Rice is the essential staple food for more than 65 percent of the people, also plays a key role in food security to 70 percent of Indian population. India is the second largest producer of rice after china. India has the largest area under rice ( $43.4 \mathrm{~m} \mathrm{ha}$ ) accounting for 29.4 percent of the global rice area with total production of 104.3 million tones and productivity of $2137 \mathrm{~kg} / \mathrm{ha}$ (Ministry of Agriculture and Farmer welfare, 2015) during 2015-16. In Telangana State, rice occupies an average of 2 million ha area and production of 6.62 million tones with average productivity $3290 \mathrm{~kg} / \mathrm{ha}$ (Statistical Year book, 2015) ${ }^{[20]}$.

Manual transplanting of the seedlings either in lines or at random in to puddle soil is the most common method of rice crop establishment used by the majority of farmers of Asian countries. The exact sowing date for transplanting of rice also plays a vital role in improving its growth and increasing the yield. The sowing time of rice crop is important for three major reasons. Firstly, it ensures that vegetative growth occurs during a period of satisfactory temperatures and high levels of solar radiation. Secondly, the optimum sowing time for each cultivar ensures the cold sensitive stage occurs when milder autumn temperatures are more likely, hence good quality is achieved (Farrell et al,. 2003) ${ }^{[4]}$. Sowing date also has a direct impact on the rate of establishment of rice seedling (Tashiro et al., 1999) ${ }^{[21]}$. Therefore, it is imperative to confirm best sowing date for higher yield levels of rice for food security.

Most of the plant nutrients required for plant growth and development comes from the soil, but the supply of nutrients is typically insufficient to meet the nutrient requirements for attaining higher rice yields. Therefore, the use of fertilizer is essential to fill the gap between the crop demands for nutrients from the soil. The nutrient management helps in improving nutrient use efficiency as it provides an approach for crop feeding with nutrients as and when required. The major benefit for farmers from improved nutrient management strategy is an increase in the profitability. Keeping in view, the present experiment was conducted for optimum sowing time of rice with better nutrient management measures. 


\section{Material and methods}

A field experiment was carried out during the Kharif, 2017 at Rice Research Centre, Agricultural Research Institute, Professor Jayashankar Telangana State Agricultural University, Rajendranagar, Hyderabad, India to study on "Effect of sowing dates and nutrient management practices on yield attributes, yield and economics of rice (Oryza sativa L.)". The experimental site is located at $17^{0} 19^{1}$ North latitude and $78^{0} 23^{1}$ East Longitude and $542.6 \mathrm{~m}$ above mean sea level. The composite soil of experimental site is clay loam in texture, low in available N $170 \mathrm{~kg} / \mathrm{ha}$ (Subbaiah and Asija, 1956), high in available $\mathrm{P} 82 \mathrm{~kg} / \mathrm{ha}$ (Olsen et al, 1954) and available $\mathrm{K} 368 \mathrm{~kg} / \mathrm{ha}\left(1 \mathrm{~N} \mathrm{NH} \mathrm{NHAC}_{4}\right.$ - extractable $\left.\mathrm{K}\right)$ with neutral in reaction $(\mathrm{pH} 7.3)$ and electrical conductivity 0.26 $\mathrm{ds} / \mathrm{m}$. The experiment was laid out in split plot design with four replications, comprises three main plot treatments i.e., sowing dates $\mathrm{M}_{1}$ - Normal sowing- first fortnight of July, $\mathbf{M}_{2-}$ 15 days after normal sowing (Late sowing) second fortnight of July, $\mathrm{M}_{3}-30$ days after normal sowing (Very late sowing) second fort night of August, six sub plot treatments i.e., $\mathrm{S}_{1^{-}}$ $100 \%$ RDF (RDF+Zn) (N-3splits@ 1/3+1/3+1/3), $\mathrm{S}_{2}-100 \%$ RDF (RDF+Zn) (N-3 splits@1/2+1/4+1/4), S $3^{-}$150\% RDF $(\mathrm{RDF}+\mathrm{Zn}) \quad(\mathrm{N}-3 \quad$ splits@ $1 / 3+1 / 3+1 / 3), \quad \mathrm{S}_{4^{-}} \quad 150 \% \quad \mathrm{RDF}$ $(\mathrm{RDF}+\mathrm{Zn}) \quad(\mathrm{N}-3 \quad$ splits@ $1 / 2+1 / 4+1 / 4), \quad \mathrm{S}_{5-} \quad 100 \%$ $\mathrm{NKZn+150 \%}$ P $\quad(\mathrm{N}-3$ splits@ $1 / 3+1 / 3+1 / 3), \quad \mathrm{S}_{6^{-}}$Absolute control (no fertilizers). In normal sowing, the test variety RNR-15048 (Telangana sona) was sown on $13^{\text {th }}$ July, transplanted on $5^{\text {th }}$ August whereas, in 15 days after normal sowing (Late sowing), crop sown on $28^{\text {th }}$ July and transplanted on $23^{\text {rd }}$ August, in 30 days after normal sowing (Very late sowing) with a spacing of $15 \times 15 \mathrm{~cm}$. The treatment means were compared using least significant difference at $5 \%$ level of significance (Gomez and Gomez, 1984) ${ }^{[5]}$. The economics were also calculated on the basis of cost of cultivation, gross returns, net returns and benefit cost ratio. The cost of cultivation for each treatment was calculated by summing all the variable cost items in the production process. Similarly, gross returns were calculated based on prevailing market price of the produce. The net returns were obtained after deducting the cost of cultivation from gross returns. Thus the benefit cost analysis was obtained by dividing total returns from a unit with total cost of a unit.

\section{Results and Discussion}

\subsection{Growth parameters}

\subsubsection{Plant population}

Plant population i.e., number of hills $/ \mathrm{m}^{2}$ was not influenced significantly by dates of sowing as there was similar number of hills $/ \mathrm{m}^{2}$ in both the sowing dates viz., normal, late and very late sowings.(Table.1).

Plant population was not influenced significantly by nutrient management practices as the plant population was similar in number viz., hills $/ \mathrm{m}^{2}$. (Table.1).

\subsubsection{Plant height}

Plant height an important growth parameter was influenced significantly by dates of sowing. Late sowing-15 days after normal soing recorded significantly higher plant height (100.1 $\mathrm{cm}$ ) over delayed sowing-30 days after normal sowing (Very late sowing) $(96.0 \mathrm{~cm})$, it remained comparable with normal sowing (Late sowing) $(99.8 \mathrm{~cm})$. (Table.1). Plant height decreased significantly as sowing was delayed. It is obvious that late sowing/planting crop had shorter growing period due to photoperiodic response. Longer growing season of normal sowing/planted crop produced taller plants and higher dry matter as compared to the delayed sowing/planting. These results are in line with Khakwani et al., (2006) ${ }^{[7]}$, Paraye and Kandalkar (1994) ${ }^{[13]}$ who reported that plant height was significantly affected by sowing dates. Similar results are also shown by Saika et al., (1989) ${ }^{[16]}$, Gravois and Hems (1998) ${ }^{[6]}$, they reported that early sowings produced taller plants than delayed sowing.

Plant height was influenced significantly by nutrient management practices. $\mathrm{S}_{4^{-}} \quad 150 \%$ RDF $(\mathrm{RDF}+\mathrm{Zn}) \quad(\mathrm{N}-3$ splits@1/2+1/4+1/4) recorded significantly higher plant height $(100.1 \mathrm{~cm})$ as compared to $\mathrm{S}_{6}$ - Absolute control (no fertilizers) $(91.7 \mathrm{~cm})$, it remained comparable with $\mathrm{S}_{1}-100 \%$ RDF (RDF+Zn) (N-3splits@1/3+1/3+1/3) (99.7 cm) and $\mathrm{S}_{2}-$ $100 \%$ RDF (RDF+Zn) (N-3 splits@ 1/2+1/4+1/4) $(100.0 \mathrm{~cm})$, $\mathrm{S}_{3}-150 \% \mathrm{RDF}(\mathrm{RDF}+\mathrm{Zn})$ (N-3 splits@ 1/3+1/3+1/3) (100.1 cm) $\mathrm{S}_{5}-100 \%$ NKZn+150\% P (N-3splits@ 1/3+1/3+1/3) $(99.8$ $\mathrm{cm})$ (Table.1).

This might be attributed due to the fact that higher doses of nutrients resulted in higher availability of nutrients in the soil for plant nourishment and further, even distribution at crop requirement, continuous availability of nutrients enhanced cell division, elongation as well as various metabolic processes which ultimately increased the plant height. The results have got close conformity with the findings of Krishna et al., (2008) [9], Dutt and Chauhan (2010) ${ }^{[3]}$ and Murthy $(2012)^{[11]}$

\subsection{Yield attributes}

\subsubsection{Number of tillers $/ \mathrm{m}^{2}$}

Number of tillers $/ \mathrm{m}^{2}$ influenced significantly by dates of sowing. Late sowing-15 days after normal sowing recorded significantly higher number of tillers $/ \mathrm{m}^{2}$ (333.8) as compared to delayed sowing-30 days after normal sowing (Very late sowing) (260.8), it remained comparable with normal sowing (328.7) (Table.1). Number of tillers $/ \mathrm{m}^{2}$ decreased significantly as sowing was delayed. Among the yield components, productive tillers are very important because the final yield is mainly a function of the number of panicle bearing tillers (productive tillers) per unit area. This increase of fertile tillers $/ \mathrm{m}^{2}$ with normal sowing, late sowing was attributed to favourable environmental conditions which enabled the plant to improve its growth and development as compared to delayed sowing. These results are in alignment with the findings of Pandey et al., (2001) ${ }^{[12]}$, Paraye and Kandalkar (1994) ${ }^{[13]}$, Bashir et al., (2010) ${ }^{[1]}$.

Number of tillers $/ \mathrm{m}^{2}$ influenced significantly by nutrient management practices. $\mathrm{S}_{3^{-}} \quad 150 \%$ RDF (RDF+Zn) (N-3 splits@1/3+1/3+1/3) recorded significantly higher number of tillers $/ \mathrm{m}^{2}(352.7)$ as compared to $\mathrm{S}_{1-} 100 \% \mathrm{RDF}(\mathrm{RDF}+\mathrm{Zn})$ (N-3splits@1/3+1/3+1/3) (325.9), $\mathrm{S}_{5}-100 \%$ NKZn+150\% P (N-3splits@1/3+1/3+1/3) (313.3), $\mathrm{S}_{6-}$ Absolute control (no fertilizers) (167.9), it remained comparable with $\mathrm{S}_{2}-100 \%$ RDF (RDF+Zn) (N-3 splits@1/2+1/4+1/4 (337.0) and $\mathrm{S}_{4}$ $150 \%$ RDF (RDF+Zn) (N-3 splits@ 1/2+1/4+1/4) (349.9) (Table.1).This might be attributed due to the fact that higher doses of nutrients resulted in higher availability of nutrients in the soil for plant nourishment and further, even distribution at peak demands of crop period, continuous availability of nutrients which enhanced cell division, elongation as well as various metabolic processes which ultimately increased the tillers and source capacity of the plant. The results have got close conformity with the findings of Krishna et al., (2008) ${ }^{[9]}$, Dutt and Chauhan (2010) ${ }^{[3]}$ and Murthy (2012) ${ }^{[11]}$. Tillering is the product of the expansion of auxiliary buds which is closely associated with the nutritional conditions of the culm 
because a tiller receives carbohydrate and nutrient from the culm during its early growth period which improved by the application of nitrogen (Tisdale and Nelson, 1975) ${ }^{[22]}$.

\subsubsection{Number of panicles $/ \mathrm{m}^{2}$}

Number of panicles $/ \mathrm{m}^{2}$ was influenced significantly by sowing dates. Normal sowing produced more number of panicles $/ \mathrm{m}^{2}$ (309.8) as compared to delayed sowing-30 days after normal sowing (Very late sowing) (229.3), it remained comparable with 15 days after normal sowing (Late sowing) (305.1) (Table.1). Numbers of panicles $/ \mathrm{m}^{2}$ are very important because the final yield is mainly function of number of panicles per unit area. The increase in number of panicles $/ \mathrm{m}^{2}$ by normal sowing, late sowing was attributed to favourable environmental conditions which enabled the plant to improve its growth and development as compared to delayed sowing. Similar results reported by Pandey et al., (2001) ${ }^{[12]}$, Paraye and Kandalkar (1994) ${ }^{[13]}$ and Bashir et al., (2010) ${ }^{[1]}$.

Number of panicles $/ \mathrm{m}^{2}$ influenced significantly by nutrient management practices. $\mathrm{S}_{3^{-}} \quad 150 \%$ RDF $(\mathrm{RDF}+\mathrm{Zn}) \quad(\mathrm{N}-3$ splits@1/3+1/3+1/3) recorded significantly higher number of tillers $/ \mathrm{m}^{2}$ (318.9) as compared to $\mathrm{S}_{1}-100 \% \mathrm{RDF}(\mathrm{RDF}+\mathrm{Zn})$ (N-3splits@1/3+1/3+1/3) (325.9), $\mathrm{S}_{6-}$ Absolute control (no fertilizers) (148.3), it remained comparable with $\mathrm{S}_{2}-100 \%$ RDF (RDF+Zn) (N-3 splits@1/2+1/4+1/4 (306.0). S4- 150\% RDF (RDF+Zn) (N-3 splits@1/2+1/4+1/4) (315.1) and $\mathrm{S}_{5-}$ $100 \% \quad \mathrm{NKZn+150 \%} \quad \mathrm{P} \quad(\mathrm{N}-3$ splits@ $1 / 3+1 / 3+1 / 3) \quad$ (301.0) (Table.1). Even distribution of nutrients at peak demands of crop period, continuous supply of nutrients in balance quantity throughout the growth period enables the rice plants to assimilate sufficient photosynthetic products and thus, increased the dry matter and source capacity, resulted in the production of increased panicles with more number of fertile grains and higher test weight, grain and straw yield. The results have got close conformity with the findings of Krishna et al., (2008) [9], Dutt and Chauhan (2010) ${ }^{[3]}$ and Murthy $(2012)^{[11]}$.

\subsubsection{Panicle length}

Panicle length was influenced significantly by dates of sowing. Normal sowing recorded more panicle length $(23.5$ $\mathrm{cm})$ as compared to delayed sowing-30 days after normal sowing (Very late sowing) $(20.8 \mathrm{~cm})$, it remained comparable with 15 days after normal sowing (Late sowing) $(23.2 \mathrm{~cm})$. (Table.1). Very late sowing, shortened the growth period of plant which reduced the leaf area, length of panicle and number of filled grains/panicle than normal sowing. These results are in line with findings of Khalifa (2009) ${ }^{[8]}$, Bashir et al., (2010) ${ }^{[1]}$, Shah and Bhurer (2005) ${ }^{[18]}$. They reported more length of panicle was visualized in normal sowing and declined in delayed sowing.

Panicle length influenced significantly by influenced significantly by nutrient management practices. $\mathrm{S}_{4-}-150 \%$ $\mathrm{RDF} \quad(\mathrm{RDF}+\mathrm{Zn}) \quad(\mathrm{N}-3 \quad$ splits@ $1 / 2+1 / 4+1 / 4) \quad$ recorded significantly higher panicle length $(23.8 \mathrm{~cm})$ as compared to $\mathrm{S}_{1-}{ }^{100 \%} \mathrm{RDF}(\mathrm{RDF}+\mathrm{Zn})$ (N-3splits@1/3+1/3+1/3) (22.1 $\mathrm{cm}), \quad \mathrm{S}_{2}-100 \%$ RDF (RDF+Zn) (N-3 splits@ 1/2+1/4+1/4 $(22.7 \mathrm{~cm}) . \mathrm{S}_{5}-100 \% \mathrm{NKZn+150 \%} \mathrm{P} \mathrm{(N-3splits@1/3+1/3+1/3)}$ $(22.5 \mathrm{~cm}), \mathrm{S}_{6-}$ Absolute control (no fertilizers) $(20.3 \mathrm{~cm})$, it remained comparable with $\mathrm{S}_{3}-150 \% \mathrm{RDF}(\mathrm{RDF}+\mathrm{Zn})(\mathrm{N}-3$ splits@1/3+1/3+1/3) (23.3 cm) (Table.1). Even distribution of nutrients at peak demands of crop period, continuous supply of nutrients in balance quantity throughout the growth period enables the rice plants to assimilate sufficient photosynthetic products and thus, increased the dry matter and source capacity, resulted in the production of increased panicles with more number of fertile grains and higher test weight, grain and straw yield. The results have got close conformity with the findings of Krishna et al., (2008) [9], Dutt and Chauhan (2010) ${ }^{[3]}$ and Murthy (2012) ${ }^{[11]}$.

\subsubsection{Panicle weight}

Panicle weight was influenced significantly by dates of sowing. Normal sowing recorded more panicle weight $(3.6 \mathrm{~g})$ as compared to delayed sowing-30 days after normal sowing (Very late sowing) $(2.4 \mathrm{~g})$, it remained comparable with 15 days after normal sowing (Late sowing) (3.4 g). (Table.1). Very late sowing, shortened the growth period of plant which reduced the leaf area, length of panicle and number of filled grains/panicle than normal sowing. These results are in conformity with findings of Mahikar et al., (2001) ${ }^{[10]}$, he reported that early sowing gave the highest number of effective tillers (110.26/m row length), panicle weight (2.89 $\mathrm{g})$, grain yield (3252 kg/ha) and straw yield (6302 kg/ha).

Panicle weight influenced significantly by nutrient management practices. $\mathrm{S}_{4}-150 \%$ RDF $(\mathrm{RDF}+\mathrm{Zn}) \quad(\mathrm{N}-3$ splits@1/2+1/4+1/4) recorded significantly higher panicle length $(3.7 \mathrm{~g})$ as compared to $\mathrm{S}_{1}-100 \% \mathrm{RDF}(\mathrm{RDF}+\mathrm{Zn})(\mathrm{N}-$ 3splits@1/3+1/3+1/3) (2.9 g), $\mathrm{S}_{6^{-}}$Absolute control (no fertilizers) (2.4g), it remained comparable with $\mathrm{S}_{2}-100 \% \mathrm{RDF}$ (RDF+Zn) (N-3 splits@ 1/2+1/4+1/4 (3.2 g). S $3-150 \%$ RDF $(\mathrm{RDF}+\mathrm{Zn})\left(\mathrm{N}-3\right.$ splits@ 1/3+1/3+1/3) (3.5 g) and $\mathrm{S}_{5}-100 \%$ NKZn+150\% P (N-3splits@1/3+1/3+1/3) (3.2 g) (Table.1). Even distribution of nutrients at peak demands of crop period, continuous supply of nutrients in balance quantity throughout the growth period enables the rice plants to assimilate sufficient photosynthetic products and thus, increased the dry matter and source capacity, resulted in the production of increased panicles with more number of fertile grains and higher test weight, grain and straw yield. The results have got close conformity with the findings of Krishna et al., (2008) ${ }^{[9]}$, Dutt and Chauhan (2010) ${ }^{[3]}$ and Murthy (2012) ${ }^{[11]}$.

\subsubsection{Test weight}

Test weight was influenced significantly by dates of sowing. Normal sowing recorded more test weight $(12.3 \mathrm{~g})$ as compared to delayed sowing-30 days after normal sowing (Very late sowing) (11.3 g), it remained comparable with 15 days after normal sowing (Late sowing) (12.2 g) (Table.1). Very late sowing, shortened the growth period of plant which reduced the leaf area, length of panicle and number of filled grains/panicle than normal sowing. This indicated that the environmental conditions like temperature, humidity was most favourable for grain development during normal sowing as compared to very late sowing. Similar results were obtained by Bashir et al., (2010) [1], Shah and Bhurer (2005) ${ }^{[18]}$, Biswas and Salokhe (2001) ${ }^{[2]}$.

Test weight influenced significantly by nutrient management practices. $\quad \mathrm{S}_{4-} \quad 150 \% \quad \mathrm{RDF} \quad(\mathrm{RDF}+\mathrm{Zn}) \quad(\mathrm{N}-3$ splits@1/2+1/4+1/4) recorded significantly higher panicle length $(12.4 \mathrm{~g})$ as compared to $\mathrm{S}_{1-} 100 \% \mathrm{RDF}(\mathrm{RDF}+\mathrm{Zn})(\mathrm{N}-$ 3splits@1/3+1/3+1/3) (12.3 g), S5-100\% NKZn+150\% P (N3splits@1/3+1/3+1/3) (12.0 g), $\mathrm{S}_{6^{-}}$Absolute control (no fertilizers) (11.1 g), it remained comparable with $\mathrm{S}_{2}-100 \%$ RDF (RDF+Zn) (N-3 splits@ 1/2+1/4+1/4 (12.2 g) and $\mathrm{S}_{3}-$ $150 \%$ RDF (RDF+Zn) (N-3 splits@1/3+1/3+1/3) (12.3 g) (Table.1). Even distribution of nutrients at peak demands of crop period, continuous supply of nutrients in balance quantity throughout the growth period enables the rice plants to assimilate sufficient photosynthetic products and thus, 
increased the dry matter and source capacity, resulted in the production of increased panicles with more number of fertile grains and higher test weight, grain and straw yield. The results have got close conformity with the findings of Krishna et al., (2008) [9], Dutt and Chauhan (2010) [3] and Murthy $(2012)^{[11]}$.

\subsection{Grain yield}

Grain yield is a function of inter play of various yield components such as productive tillers, number of grains /panicle and 1000 seed weight. Grain yield influenced significantly by dates of sowing. Normal sowing recorded more grain yield (5700 kg/ha) as compared to delayed sowing-30 days after normal sowing (Very late sowing) (2839 $\mathrm{kg} / \mathrm{ha}$ ), it remained comparable with late sowing-15 days after normal sowing $(5758 \mathrm{~kg} / \mathrm{ha})$ (Table.1). The decreasing trend in grain yield in very late sowing might be associated with significantly lower number of productive tillers $/ \mathrm{m}^{2}$, number of grains/panicles and test weight. The higher grain yield was attributed to more number of productive tillers, higher panicle length, panicle weight and increased test weight. These results are also in line with findings of Nayak et al., (2003), Shah and Bhurer (2005) ${ }^{[18]}$, Khakwani et al., (2006) [7], Bashir et al., (2010) ${ }^{[1]}$

Grain yield influenced significantly by nutrient management practices. $\quad \mathrm{S}_{4^{-}} \quad 150 \% \quad \mathrm{RDF} \quad(\mathrm{RDF}+\mathrm{Zn}) \quad(\mathrm{N}-3$ splits@1/2+1/4+1/4) recorded significantly higher grain yield (5842 kg/ha) as compared to $\mathrm{S}_{1-} 100 \% \mathrm{RDF}(\mathrm{RDF}+\mathrm{Zn})(\mathrm{N}-$ 3splits@1/3+1/3+1/3) (4900 kg/ha) and $\mathrm{S}_{5}-100 \%$ NKZn+150\% P (N-3splits@1/3+1/3+1/3) (4905 kg/ha), $\mathrm{S}_{6-}$ Absolute control (no fertilizers) $(2130 \mathrm{~kg} / \mathrm{ha})$, it remained comparable with $\mathrm{S}_{2}-100 \%$ RDF (RDF+Zn) (N-3 splits@1/2+1/4+1/4 (5259 kg/ha) S $3-150 \%$ RDF (RDF+Zn) (N-3 splits@1/3+1/3+1/3) (5557 kg/ha) (Table.1). Grain yield is the final product which depends upon the development of yield components such as effective tillers, panicle length, test weight, total and filled grains/panicle. Even distribution of nutrients at peak demands of crop period and continuous supply of nutrients in balance quantity throughout the crop growth period enables the rice plants to assimilate sufficient photosynthetic products and thus, increased the dry matter and source capacity resulted in increased of yield attributes and finally yield of grain. The results have got close conformity with the findings of Krishna et al., (2008) ${ }^{[9]}$, Dutt and Chauhan (2010) ${ }^{[3]}$ and Murthy (2012) ${ }^{[11]}$.

\subsection{Straw yield}

Straw yield was influenced significantly by dates of sowing. Normal sowing recorded more straw yield $(6938 \mathrm{~kg} / \mathrm{ha})$ as compared to delayed sowing-30 days after normal sowing (Very late sowing) $(3454 \mathrm{~kg} / \mathrm{ha})$, it remained comparable with late sowing-15 days after normal sowing (6938 kg/ha) (Table.1). Sowing date has a direct impact on the rate of establishment of rice seedling (Tashiro et al., 1999) ${ }^{[21]}$. Normal sowing (optimum date of sowing) is the best time of sowing for important properties such as maximum tillering, panicle initiation, chlorophyll content, leaf area index, sink capacity, panicle length, number of panicles $/ \mathrm{m}^{2}$, grain and straw yields. These results are in conformity with findings of Khalifa (2009) ${ }^{[8]}$, Bashir et al., (2010) ${ }^{[1]}$, Shah and Bhurer $(2005)^{[18]}$.

Straw yield influenced significantly by nutrient management practices. $\quad \mathrm{S}_{4-} \quad 150 \% \quad \mathrm{RDF} \quad(\mathrm{RDF}+\mathrm{Zn}) \quad(\mathrm{N}-3$ splits@1/2+1/4+1/4) recorded significantly higher Straw yield
(7003 kg/ha) as compared to $\mathrm{S}_{1-} 100 \% \mathrm{RDF}(\mathrm{RDF}+\mathrm{Zn})(\mathrm{N}-$ 3splits@ 1/3+1/3+1/3) (6120 kg/ha), S5-100\% NKZn+150\% P (N-3splits@1/3+1/3+1/3) (5877 kg/ha), S $6^{-}$Absolute control (no fertilizers) $(6120 \mathrm{~kg} / \mathrm{ha})$, it remained comparable with $\mathrm{S}_{2-}$ $100 \%$ RDF (RDF+Zn) (N-3 splits@ 1/2+1/4+1/4 (5450 kg/ha) and $\mathrm{S}_{3^{-}} 150 \% \mathrm{RDF}(\mathrm{RDF}+\mathrm{Zn}) \quad(\mathrm{N}-3$ splits@ $1 / 3+1 / 3+1 / 3)$ $(5564 \mathrm{~kg} / \mathrm{ha})$ (Table.1). Straw yield is the final product which depends upon the development of yield components such as effective tillers, panicle length, test weight, total and filled grains/panicle. Even distribution of nutrients at peak demands of crop period and continuous supply of nutrients in balance quantity throughout the crop growth period enables the rice plants to assimilate sufficient photosynthetic products and thus, increased the dry matter and source capacity resulted in increased of yield attributes and finally yield of grain. The results have got close conformity with the findings of Krishna et al., (2008) [9], Dutt and Chauhan (2010) ${ }^{[3]}$ and Murthy $(2012)^{[11]}$.

\section{Economics}

The gross and net returns were higher in normal and late sowings. In delayed sowing-30 days after normal sowing (Very late sowing) increased cost of cultivation, decreased gross returns resulted in negative net returns and $\mathrm{BC}$ ratio. In normal and late sowings, higher grain and straw yields resulted in increased gross, net returns and $\mathrm{BC}$ ratio, reduced cost of cultivation further increased the net returns $(45,179)$, (Rs. 46,147) and BC ratios (0.90), (0.92) respectively (Table 2).

Among the nutrient management practices, cost of cultivation was higher in $\mathrm{S}_{4-} \quad 150 \% \quad \mathrm{RDF} \quad(\mathrm{RDF}+\mathrm{Zn}) \quad(\mathrm{N}-3$ splits@ 1/2+1/4+1/4) (Rs.55, 000) and $\mathrm{S}_{3^{-}}$150\% RDF (RDF+Zn) (N-3splits@1/3+1/3+1/3) (Rs. 55,000). The net returns (Rs. 42,550) as well as return per rupee invested (1: $0.77)$ is maximum in $\mathrm{S}_{2-} 150 \%$ RDF (RDF+Zn) (N-3 splits@1/2+1/4+1/4) (Rs. 37,815) (0.75) respectively (Table $2)$. The higher yields of grain and straw recorded in these treatments were the main reason for higher benefit cost ratio though cost of cultivation was higher than other treatments.

\section{Conclusion}

On the basis of results obtained from the present investigation, it is concluded that normal and late sowings are found to be optimum, beneficial in improving the growth parameters, yield attributes and yield of rice as the synchronization of the critical phenophases with the favourable weather regime ensures promising crop yield which is only possible by adjusting the sowing date. Experimental findings indicate that $\mathrm{S}_{2}-100 \% \mathrm{RDF}(\mathrm{RDF}+\mathrm{Zn})$ (N-3 splits@1/2+1/4+1/4), S $3^{-}$150\% RDF (RDF+Zn) (N-3 splits@1/3+1/3+1/3), $\quad \mathrm{S}_{4^{-}} \quad 150 \% \quad \mathrm{RDF} \quad(\mathrm{RDF}+\mathrm{Zn}) \quad(\mathrm{N}-3$ splits@1/2+1/4+1/4) produced the comparable grain yields. $\mathrm{S}_{2^{-}} \quad 100 \%$ RDF (RDF+Zn) (N-3splits@ 1/2+1/34+1/4) produced the grain yield which was obtained in $\mathrm{S}_{4-} 150 \%$ RDF (RDF+Zn) (N-3 splits@1/2+1/4+1/4), with 50\% reduction of recommended dose of fertilizer in $\mathrm{S}_{4-} 150 \% \mathrm{RDF}$ $(\mathrm{RDF}+\mathrm{Zn})\left(\mathrm{N}-3\right.$ splits@ 1/2+1/4+1/4). Hence, $\mathrm{S}_{2}-100 \% \mathrm{RDF}$ (RDF+Zn) (N-3splits@1/2+1/4+1/4) found to be better with $50 \%$ saving of recommended dose of fertilizer which was used in $\mathrm{S}_{4-}$ 150\% RDF (RDF+Zn) (N-3 splits@ 1/2+1/4+1/4) for obtaining higher net returns, $\mathrm{BC}$ ratio.

Hence, normal and late sowings with $\mathrm{S}_{2^{-}} 100 \% \mathrm{RDF}$ (RDF+Zn) (N-3 splits@1/2+1/4+1/4) found to be optimum and better for higher productivity and profitability. 
Table 1: Growth, yields attributes and yield as influenced by dates of sowing and nutrient management practices

\begin{tabular}{|c|c|c|c|c|c|c|c|c|c|}
\hline Treatments & \begin{tabular}{|c|}
$\begin{array}{c}\text { Plant } \\
\text { populat- } \\
\text { ion } / \mathbf{m}^{2}\end{array}$ \\
\end{tabular} & $\begin{array}{c}\text { Plant } \\
\text { height } \\
(\mathrm{cm})\end{array}$ & $\begin{array}{l}\text { Tillers } \\
\left(\mathrm{No} / \mathrm{m}^{2}\right)\end{array}$ & $\begin{array}{c}\text { Panicles } \\
\left(\mathbf{n o} / \mathbf{m}^{2}\right)\end{array}$ & $\begin{array}{c}\text { Panicle } \\
\text { length } \\
(\mathrm{cm})\end{array}$ & \begin{tabular}{|c|} 
Panicle \\
weight \\
(g)
\end{tabular} & $\begin{array}{l}\text { Test } \\
\text { wt. } \\
\text { (g) }\end{array}$ & $\begin{array}{c}\text { Grain } \\
\text { yield } \\
\text { (kg/ha) }\end{array}$ & \begin{tabular}{|c}
$\begin{array}{c}\text { Straw } \\
\text { yield } \\
\text { (kg/ha) }\end{array}$ \\
\end{tabular} \\
\hline \multicolumn{10}{|c|}{ Main plot } \\
\hline Normal sowing & 41.9 & 99.8 & 328.7 & 309.8 & 23.5 & 3.6 & 12.3 & 5700 & 6938 \\
\hline Late sowing & 41.8 & 100.1 & 333.8 & 305.1 & 23.2 & 3.4 & 12.2 & 5758 & 7017 \\
\hline Very late sowing & 42.0 & 96.0 & 260.8 & 229.3 & 20.8 & 2.4 & 11.3 & 2839 & 3454 \\
\hline $\mathrm{SEm} \pm$ & 0.08 & 0.64 & 6.9 & 6.03 & 0.49 & 0.12 & 0.04 & 221 & 269 \\
\hline $\mathrm{CD}(\mathrm{p}=0.05)$ & N.S. & 2.48 & 26.98 & 23.51 & 1.90 & 0.47 & 0.16 & 863 & 1051 \\
\hline \multicolumn{10}{|c|}{ Sub plot } \\
\hline $100 \%$ RDF + Zn of the location (N-3 splits @ 1/3+1/3+1/3) & 42.0 & 99.7 & 325.9 & 299.0 & 22.1 & 2.9 & 12.0 & 4900 & 6120 \\
\hline $100 \%$ RDF + Zn of the location (N-3 splits @ 1/2+1/4+1/4) & 42.0 & 100.0 & 337.0 & 306.0 & 22.7 & 3.2 & 12.2 & 5259 & 6302 \\
\hline $150 \%$ RDF + Zn of the location (N-3 splits @ 1/3+1/3+1/3) & 41.9 & 100.1 & 352.7 & 318.9 & 23.3 & 3.5 & 12.3 & 5557 & 6654 \\
\hline $150 \%$ RDF + Zn of the location (N-3 splits @ $1 / 2+1 / 4+1 / 4)$ & 41.9 & 100.6 & 349.9 & 315.1 & 23.8 & 3.7 & 12.4 & 5842 & 7003 \\
\hline $100 \%$ NKZn + 150\% P (N-3 splits @ 1/3+1/3+1/3) & 41.9 & 99.8 & 313.3 & 301.0 & 22.5 & 3.2 & 11.8 & 4905 & 5877 \\
\hline Absolute control (no fertilizer) & 41.6 & 91.7 & 167.9 & 148.3 & 20.3 & 2.4 & 11.1 & 2130 & 2861 \\
\hline $\mathrm{SEm} \pm$ & 0.11 & 0.63 & 8.69 & 6.25 & 0.17 & 0.17 & 0.09 & 204 & 245 \\
\hline $\mathrm{CD}(\mathrm{p}=0.05)$ & N.S. & 1.81 & 25.12 & 18.07 & 0.49 & 0.51 & 0.26 & 590 & 710 \\
\hline
\end{tabular}

Table 2: Economics of rice as influenced by dates of sowing and nutrient management practices

\begin{tabular}{|c|c|c|c|c|}
\hline Treatments & Gross returns (Rs/ha) & Cost of cultivation (Rs/ha) & Net returns (Rs/ha) & $\mathrm{B}: \mathrm{C}$ \\
\hline \multicolumn{5}{|c|}{ Main plot treatments } \\
\hline Normal sowing & 95,179 & 50,000 & 45,179 & 0.90 \\
\hline Late sowing & 96,147 & 50,000 & 46,147 & 0.92 \\
\hline Very late sowing & 47,406 & 51,000 & - & - \\
\hline \multicolumn{5}{|c|}{ Sub plot treatments } \\
\hline $100 \% \mathrm{RDF}+\mathrm{Zn}$ of the location (N-3 splits @ $1 / 3+1 / 3+1 / 3)$ & 81,820 & 50,000 & 31,820 & 0.63 \\
\hline $100 \% \mathrm{RDF}+\mathrm{Zn}$ of the location (N-3 splits @ 1/2+1/4+1/4) & 87,815 & 50,000 & 37,815 & 0.75 \\
\hline $150 \% \mathrm{RDF}+\mathrm{Zn}$ of the location (N-3 splits @ 1/3+1/3+1/3) & 92,791 & 55,000 & 37,791 & 0.68 \\
\hline $150 \% \mathrm{RDF}+\mathrm{Zn}$ of the location (N-3 splits @ 1/2 + 1/4 + 1/4) & 97,550 & 55,000 & 42,550 & 0.77 \\
\hline $100 \%$ NKZn + 150\% P (N-3 splits @ 1/3 + 1/3 + 1/3) & 81,904 & 51,200 & 30,704 & 0.59 \\
\hline Absolute control (no fertilizer) & 35,567 & 46,000 & - & - \\
\hline
\end{tabular}

\section{References}

1. Bashir MU, Akbar N, Iqbal A, Zaman H. Effect of different sowing dates on yield and yield components of direct seeded coarse rice (Oryza sativa L.,). Pakistan J Agri. Sci. 2010; 47(4): 361-365.

2. Biswas PK, Salokhe VM. Effects of planting date, intensity of tiller separation and plant density on the yield of transplanted rice (Oryza sativa L.,). Journal of Agric. Sci. 2001; 137(3):279-287.

3. Dutta M, Chauhan BS. Effect of nutrient management practice on the performance of upland rice in a newly developed terraced land. Indian Agriculture. 2010; 54 :( 1/2):13-21.

4. Farrell TC, Fox K, Williams RL, Fukai S, Lewin LG. Avoiding low temperature damage in Australia's rice industry with photoperiod sensitive cultivars. Proceedings of the $11^{\text {th }}$ Australian Agronomy Conference. Deakin University, Geelong, (Feb.2-6), Victoria, Australia, 2003.

5. Gomez KA, Gomez AA. Statistical Procedures for Agricultural Research, $2^{\text {nd }}$ Edition. John Wiley and Sons. New York, 1984, 639.

6. Gravois KA, Helms RS. Seeding date effects on rough rice yield and head rice and selection for stability. Euphytica. 1998; 102(2):151-161.

7. Khakwani AA, Zubair M, Mansoor M, Naveed K, Shah IH, Wahab A et al. Agronomic and morphological parameters of rice crop as affected by date of transplanting. Journal of Agronomy. 2006; 5(2):248-250.

8. Khalifa AABA. Physiological evaluation of some hybrid rice varieties under different sowing dates. Australian Journal of Crop Science. 2009; 3(3):178-183.
9. Krishna A, Biradarpatil NK, Channappayoundar BB. Influence of System of Rice Intensification (SRI) cultivation on seed yield and quality. Karnataka J Agril. Sci. 2008; 21(3):369-372.

10. Mahikar GH, Parmar DV, Pandey CT. Effect of planting date on some agronomic traits and grain yield of upland rice varieties. Journal of Sustainable Development in Agriculture and Environment. 2001; 55:35-40.

11. Murthy RK. Productivity and economics of rainfed rice as influenced by integrated nutrient management. Madras Agricultural Journal. 2012; 99(4/6):266-270.

12. Pandey N, Verma AK, Thripathi RS. Effect of planting time, nitrogen on tillering pattern, dry matter accumulation and grain yield of hybrid rice (Oryza sativa L.,). Indian Journal of Agric. Sci. 2001; 71(5):337-338.

13. Paraye PM, Kandalkar VS. Effect of Seeding age on long duration, Rainfed varieties of rice under delayed transplanting. Indian Journal of Agric. Scie. 1994; 64(3):187-188.

14. Ramulu Ch, Raghu Rami Reddy P, Narsaiah E. Effect of different establishment methods and nitrogen levels on yield attributes, yield, nutrient uptake and economics of rice (Oryza sativa L.,). The journal of Research PJTSAU. 2019; 47(3):27-32.

15. Revathi P, Suneetha Devi KB, Gopal Reddy B, Praveen Rao V, Padmaja G, Shivashankar A. Influence of planting methods and integrated nutrient management practices on yield attributes, yield and economics of rice (Oryza sativa L.,). The journal of Research PJTSAU. 2016; 44(4):25-32. 
16. Saikia L, Chandra K, Mahanta TC. Performance of late transplanting rice in Assam. Inernational Rice Resaerch News letter. 1989; 14(1):21.

17. Satish A, Raghu Rami Reddy P, Avil Kumar K, Uma Devi M. Dry matter production and nutrient uptake of rice (Oryza sativa L.,). As influenced by systems of rice cultivation and irrigation regimes in puddle soil. The journal of Research PJTSAU. 2016; 44(3):46-49.

18. Shah LM, Bhurer KP. Response of seeded rice varieties to sowing dates. Nepal Agric. Res. Journal. 2005; 6:3538.

19. Singh NP, Singh MK, Tyagi S, Singh SS. Effect of Integrated Nutrient Management on Growth and Yield of Rice (Oryza sativa L.). International Journal of Current Microbiology and Applied Sciences. 2018; 7:3671-3681.

20. Statistical Year Book. Directorate of Economics and Statistics, Government of Telanagana, Hyderabad, 2015.

21. Tashiro T, Saigusa M, Shibuya K. A trial of No tillage Direct seeding Rice (Oryza sativa L.,) at early spring in cold climate Region in Japan. Japanese journal of Crop sciences. 1999; 68(1):146-150.

22. Tisdale SL, Nelson WL. Soil Fertility and Fertilizers, $3^{\text {rd }}$ Edition. The MacMillan Publ. Co. Inc., New York, 1975. 